\title{
ANTHROPOMETRIC MEASUREMENTS, DIETARY HABITS, SERUM LIPID AND GLUCOSE LEVELS IN RELATION TO HIGH BLOOD PRESSURE AMONG ADOLESCENT BOYS AND GIRLS IN CROATIA
}

\author{
Olgica Martinis ${ }^{1}$, Miran Čoklo², Jasna Aladrović ${ }^{3}$, Anja Belavićc ${ }^{4}$ and Saša Missoni ${ }^{5,6}$ \\ ${ }^{1}$ Croatian Education and Teacher Training Agency, Zagreb, Croatia; \\ ${ }^{2}$ Centre for Applied Bioanthropology, Institute for Anthropological Research, Zagreb, Croatia; \\ ${ }^{3}$ University of Zagreb, Faculty of Veterinary Medicine, Zagreb, Croatia; \\ ${ }^{4}$ Croatian Institute of Public Health, Zagreb, Croatia; \\ 5Josip Juraj Strossmayer University of Osijek, Faculty of Medicine, Osijek, Croatia; \\ ${ }^{6}$ Institute for Anthropological Research, Zagreb, Croatia
}

\begin{abstract}
SUMMARY - The aim was to determine differences in anthropometric measurements, dietary habits, serum lipid and glucose levels in relation to high blood pressure (BP) among adolescent boys and girls in Croatia. The specific aim was to determine the effect of dietary habits and lifestyle on high $\mathrm{BP}$ in adolescents according to sex. The study included $260(68.2 \%)$ adolescent girls and $121(31.8 \%)$ boys with anthropometric data obtained (without missing values) from 246 girls and 111 boys. Participants answered questions from the questionnaire and anthropometric BP and blood test values were obtained. Non-parametric tests were used in analyses of reference intervals of systolic and diastolic BP in adolescent boys and girls according to age. High BP was defined as $\geq 90^{\text {th }}$ percentile for adolescent girls and boys, with a value of $\geq 135 / 87.5 \mathrm{~mm} \mathrm{Hg}$. Mann-Whitney $\mathrm{U}$ test was used to analyze differences in anthropometric and laboratory values between the groups of girls and boys with high $\left(\leq 90^{\text {th }}\right.$ percentile) and normal BP. Increase in systolic and diastolic BP was noted in the adolescents. In girls, BP values showed a decreasing systolic and increasing diastolic BP trend with age. Girls with high BP had a significantly higher body mass index (BMI) $(\mathrm{p}=0.020)$, waist circumference (WC) $(\mathrm{p}=0.002)$, waist-to-height ratio $(\mathrm{WHtR})(\mathrm{p}=0.016)$, waist-to-hip ratio $(\mathrm{WHR})(\mathrm{p}=0.043)$, hip circumference $(\mathrm{HC})(\mathrm{p}=0.015)$, triglyceride $(\mathrm{TG})$ levels $(\mathrm{p}=0.021)$, higher prevalence of unhealthy diet at school breakfast $(\mathrm{p}=0.008)$ and lower prevalence of eating fish $(\mathrm{p}=0.02)$. Boys with high BP had a significantly higher BMI $(p=0.045)$, WC $(p=0.004)$, WHtR $(p=0.017)$, WHR $(p=0.022)$ and higher prevalence of eating meat products $(\mathrm{p}=0.015)$. Effective health interventions are needed to reduce the risk of developing cardiovascular diseases and preventing age-related illness.
\end{abstract}

Key words: Adolescents; Anthropometric measurements; Blood tests; Dietary habits; High blood pressure; Cardiovascular disease

\section{Introduction}

Adolescence is a period of intense physical growth and cognitive development. Accelerated growth in

Correspondence to: Olgica Martinis, $M A$, Croatian Education and Teacher Training Agency, Donje Svetice 38, HR-10000 Zagreb, Croatia

E-mail: olgica.martinis69@gmail.com

Received March 3, 2019, accepted April 16, 2019 height is an indicator of natural physical changes during transition from childhood to adolescence. The fastest physical growth occurs on average two years earlier in girls than in boys. There are differences in the rate of growth in height and weight gain among adolescents of the same chronological age ${ }^{1}$.

Anthropometric measurements are used to monitor adolescent growth during regular periodic health examinations, and the results obtained are important 
for the prevention of a number of chronic diseases such as cardiovascular diseases (CVD), obesity or malnutrition, and/or a nutritionally poor diet. Body and weight dissatisfaction, meal skipping and snacking instead of eating meals are among frequent behaviors that can impact health in a negative way ${ }^{2}$. On the other hand, it is well known that healthy eating is of great importance for good health, as well as for maintaining that degree of health ${ }^{3}$. The prevalence of overweight (including obesity) in children and adolescents in the World Health Organization European region is alarming. An increasing prevalence of overweight children has been reported in many Eastern European countries since $2002^{4}$. Excessive weight during adolescence is likely to continue into adulthood. Therefore, education about proper dietary habits, regular health care, control of body weight and regular medical examinations for adolescents are needed in particular ${ }^{5}$. Assessment of weight status in children and adolescents includes anthropometric measurements and indicators calculated on their basis, such as body mass index (BMI), waist-to-hip ratio (WHR) and waist-toheight ratio (WHtR), as they were shown to correlate strongly with risk factors for $\mathrm{CVD}^{6}$. WHtR is an indicator that reflects a relationship, changing with age, between the rate of waist circumference (WC) increase and body height. It is a simple indicator for estimating the risk factors for CVD during clinical screening, and it seems to be even more reliable than $\mathrm{WC}$ and $\mathrm{BMI}^{6}$. There is growing evidence that children and adolescents with high blood pressure (BP) are much more common than previously thought. The relatively high prevalence of increased $\mathrm{BP}$ in children is a serious public health concern around the world ${ }^{7}$. High BP during adolescence occasionally develops into adult hypertension, thereby emphasizing the importance of tracking the phenomenon not just epidemiologically but also clinically ${ }^{8}$. Hypertension during childhood and adolescence is associated with elevated stroke mortality in midlife. This finding warrants further large-scale long-term follow-up studies to corroborate and address the distant effects of adolescent hypertension $^{9}$. It is well known that being overweight and obese are some of the most important risk factors for high $\mathrm{BP}$ in children and adolescents ${ }^{10}$. Although hypertension is described in children and adolescents, there are many knowledge gaps on how to best define and manage high $\mathrm{BP}$ in adolescents ${ }^{11}$. $\mathrm{BP}$ values of children and adolescents have been previously studied, and other factors that contribute to high levels of BP should be further assessed. Research using data on the population of children and adolescents with high $\mathrm{BP}$ in relation to sex is still scant. Therefore, it is essential to establish evidence-based treatment guidelines ${ }^{11}$.

Based on the above, the aim of the study was to investigate differences in anthropometric measurements, dietary habits, serum lipid and glucose levels relative to high BP among adolescent boys and girls in Croatia.

\section{Subjects and Methods}

\section{Participants}

Participants were high school students from Croatia, selected on the basis of a preliminary questionnaire on adolescent interest in improving dietary habits. For those students who showed interest, an informed consent was obtained from parents, as well as from school principals and the Ethics Committee of the University of Zagreb School of Medicine and the Ministry of Science, Education and Sports. The participants differed according to age (14 to 17 years) and gender (girls and boys). The number of surveyed participants according to grade and gender was 260 (68.2\%) adolescent girls and 121 (31.8\%) boys with anthropometric data obtained (without missing values) from 246 girls and 111 boys.

\section{Questionnaire}

The title of the questionnaire was Questionnaire on Nutritional Status, Health Condition and Dietary Habits of Adolescents and consisted of the following two groups of questions: Dietary Habits of the Adolescents and Nutrition-Related Lifestyle. The first set of questions included information about the school, high school grade, town (place of residence), gender, and age. These were followed by 8 items referring to dietary habits of the adolescents, as follows: Daily I usually have three main meals (breakfast, lunch and dinner); For breakfast at school, I eat one of the following: leafy dough, various white bread flakes, biscuits, snacks; When I'm thirsty, I prefer to drink water; I eat fresh seasonal fruit; I eat fresh seasonal vegetables; Of the meat products, I mostly eat pate (chicken, liver), meat salami and sausages; I eat white fish; I eat oily fish (anchovy, sardine, tuna). The second part of 
the Questionnaire contained four items referring to the Nutrition-Related Lifestyle: I exercise regularly; I smoke cigarettes; I drink alcohol; Every day I find time for rest and relaxation. Throughout the questionnaire, the 5-degree Likert scale was used, ranging from never (1) to always (5). The students completed the questionnaire within 45 minutes; however, it took less than 45 minutes for most of them.

In our study, the questionnaires showed satisfactory reliability and construct validity. These metric characteristics of the two completely new measuring instruments (Dietary Habits of the Adolescents and Nutrition-Related Lifestyle) support the assumption that the application of these instruments should be considered beneficial in the future.

\section{Anthropometry}

Anthropometric measurements were performed according to standard techniques ${ }^{12}$. The same instrumentation was used in all study participants and the same trained personnel performed measurements in all participants.

Body weight was measured on a self-zeroing digital weight scale (precision $0.1 \mathrm{~kg}$; Beurer, Germany), and height was measured with an anthropometer $\left(\mathrm{Si}^{-}\right.$ ber Hegner, Switzerland) to the nearest millimeter. Height and weight were measured in light clothes and without shoes. Height was recorded in centimeters to two decimal places. BMI was calculated as weight divided by height square $\left(\mathrm{kg} / \mathrm{m}^{2}\right)^{13}$. WC was measured using a measuring tape to the nearest $0.1 \mathrm{~cm}$ at the high point of the iliac crest during minimal respiration when the participant was in standing position ${ }^{14}$. $\mathrm{WHtR}$ was calculated according to the formula: waist circumference $(\mathrm{cm}) /$ height $(\mathrm{cm})$. Hip circumference (HC) was measured at the point of greatest circumference in the buttocks using a measuring tape. WHR was calculated according to the formula: waist circumference $(\mathrm{cm}) /$ hip circumference $(\mathrm{cm})^{15}$. Skinfold thickness was measured in millimeters using special calipers (Harpenden, Baty International, UK). The skinfold thickness method is based on measuring a pinch of skin precisely at several standardized sites on the body to determine the subcutaneous fat layer.

In our study, the landmark was determined by measuring the midpoint between the acromion process of the right humerus (shoulder) and the olecranon process (elbow) of the same limb. The midpoint was marked on the skin anteriorly to measure the biceps skinfold and posteriorly to measure the triceps skinfold with the arm by the side of the body ${ }^{16}$.

\section{Blood pressure measurements}

Blood pressure measurements were obtained from the right arm by auscultators. Arm circumference was measured with a tourniquet at the midpoint of the upper arm between the acromion and olecranon before BP measurements. BP was measured twice using a mercury sphygmomanometer (S\&K Miniatur 300B, Riester, Germany). The first Korotkoff phase was recorded as systolic BP (SBP) and the fifth Korotkoff phase was used to define diastolic BP (DBP). After 5 -minute rest, the average of the last two $\mathrm{BP}$ readings was used for data analyses. BP measurements were taken during one visit to the high schools.

Systolic BP and DBP age related reference intervals were expressed with $5^{\text {th }}, 10^{\text {th }}, 90^{\text {th }}$ and $95^{\text {th }}$ percentile in addition to mean $\mathrm{BP}$ for each gender.

Based on published data ${ }^{17}$, study participants were classified into two BP groups of normal BP (average $\mathrm{BP}<90^{\text {th }}$ percentile) and high-BP (average $\mathrm{BP} \geq 90^{\text {th }}$ percentile).

\section{Blood collection and biochemical measurements}

Blood samples were collected after 12-h fast using standard venipuncture performed by staff well trained in drawing blood. The blood was centrifuged by standardized protocol, separated in re-labelled vials, and shipped to the Clinical Department of Laboratory Diagnostics, Dubrava University Hospital, where the samples were processed. Serum was stored frozen at $-20^{\circ} \mathrm{C}$ until analysis.

Serum glucose levels were determined by hexokinase method, serum total cholesterol (TC) level by CHOD-PAP method, serum triglycerides (TG) by GPO-PAP method, and serum high-density lipoprotein cholesterol (HDL-c) by automated homogeneous assays on a Beckman Coulter AU 680 analyzer (Beckman, Minneapolis, USA) with reagent kits from the same manufacturer. The coefficient of variation for all blood measurements was under $5 \%$ for both intra-assay quality controls.

\section{Statistical analysis}

Data are shown in tables and figures. The normality of distribution of continuous variables was tested by 


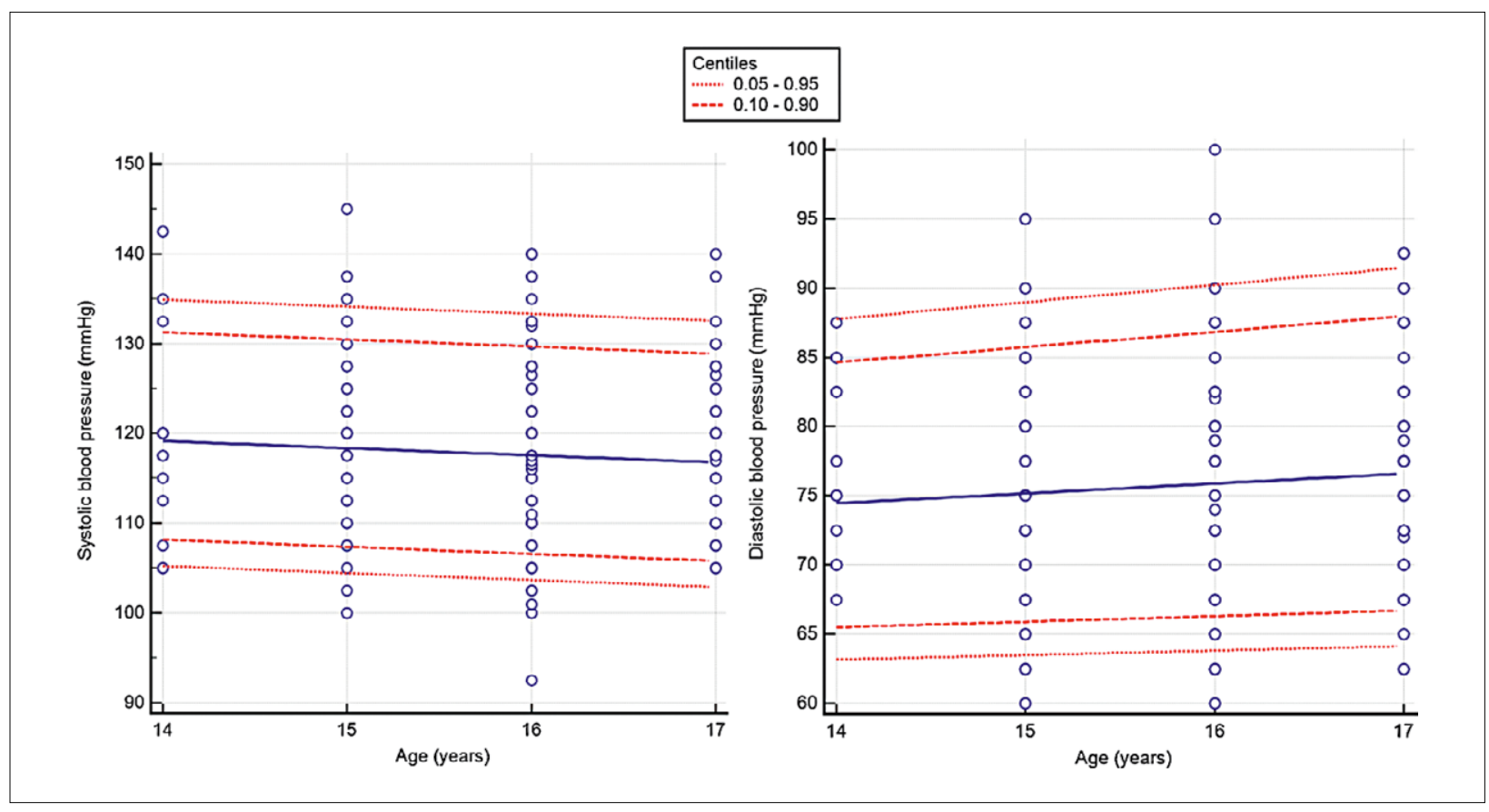

Fig. 1. Systolic and diastolic blood pressure reference intervals in adolescent girls according to age (measurements transformed logarithmically).

Kolmogorov-Smirnov test and non-parametric tests were used in the following analyses. Categorical variables were expressed as frequencies and corresponding percentages, and quantitative variables as medians and interquartile ranges $\left(25^{\text {th }}\right.$ to $75^{\text {th }}$ percentile). SBP and DBP age related reference intervals were shown with $5^{\text {th }}, 10^{\text {th }}, 90^{\text {th }}$ and $95^{\text {th }}$ percentile in addition to mean BP for each gender. The methodology for reference interval for age is based on the methods described ${ }^{18-20}$. Since distribution of the measurements showed skewness at different ages, the measurements were transformed logarithmically. The transformed measurements were modelled on age using weighted polynomial regression ${ }^{21}$. This regression model gives the mean of the (transformed) measurements as a function of age.

The $\chi^{2}$-test was used to analyze differences in dietary habits between BP groups of adolescent girls and boys separately. Mann-Whitney $U$ test was used to analyze differences in anthropometric and laboratory values between high ( $\geq 90^{\text {th }}$ percentile) and normal BP groups of adolescent girls and boys.

The level of statistical significance was set at $\mathrm{p}<0.05$. Data analysis software system MedCalc Statistical Software version 18.11 (MedCalc Software bvba, Os- tend, Belgium; http://www.medcalc.org; 2018) was used in all statistical procedures.

\section{Results}

The study included 260 (68.2\%) adolescent girls and 121 (31.8\%) boys with anthropometric data obtained (without missing values) on 246 girls and 111 boys. Mean $( \pm \mathrm{SD})$ age was $15.8 \pm 0.9$ years in girls and $15.5 \pm 0.8$ years in boys, with minimum of 14 years and maximum of 17 years for both genders. SBP and DBP reference intervals in adolescent girls and boys according to age are shown in Figures 1 and 2. In girls, there was a trend of SBP decrease and DBP increase with age. In comparison, adolescent boys had a rising trend in both SBP and DBP.

Differences in anthropometric and laboratory values between high $\left(\geq 90^{\text {th }}\right.$ percentile) and normal BP groups of adolescent girls are shown in Table 1. Girls with high $\left(\geq 90^{\text {th }}\right.$ percentile $) \mathrm{BP}(>135 / 87.5 \mathrm{~mm} \mathrm{Hg})$ had a significantly higher BMI $(\mathrm{p}=0.020)$, WC $(p=0.002)$, WHtR ( $p=0.016)$, WHR ( $p=0.043), H C$ $(p=0.015)$ and TG levels $(p=0.021)$ compared to those who did not have high BP. 


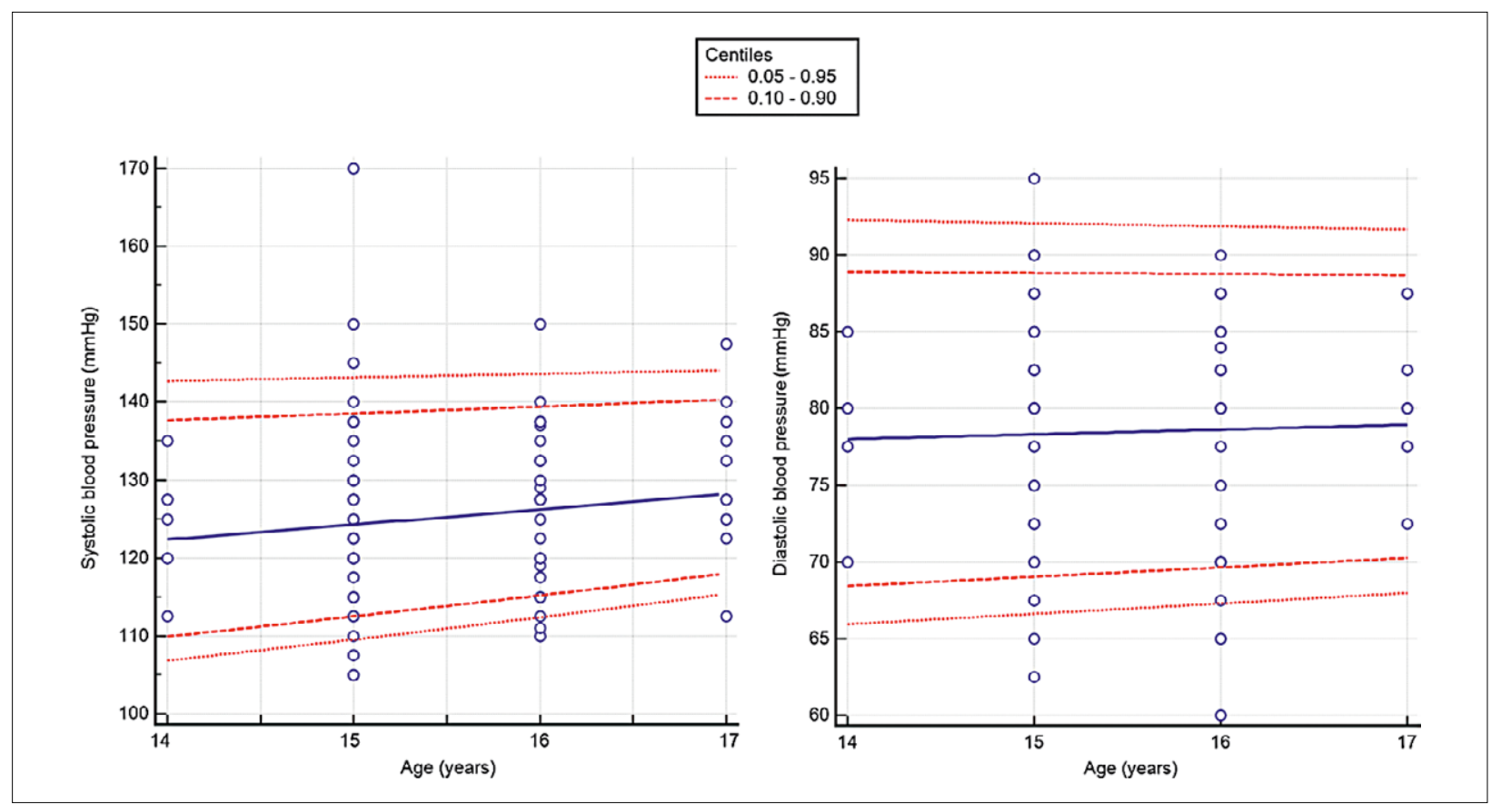

Fig. 2. Systolic and diastolic blood pressure reference intervals in adolescent boys according to age (measurements transformed logarithmically).

Adolescent boys with high BP had a significantly higher BMI $(\mathrm{p}=0.045)$, WC $(\mathrm{p}=0.004)$, WHR $(\mathrm{p}=0.022)$ and WHtR $(\mathrm{p}=0.017)$ (Table 2).

Relationship of dietary habits with high BP in adolescent girls is shown in Table 3. Girls with high BP had a significantly higher prevalence of eating leafy dough, various white bread flakes, biscuits, snacks at school breakfast $(\mathrm{p}=0.008)$ and lower prevalence of eating white $(\mathrm{p}=0.021)$ and oily fish $(\mathrm{p}=0.026)$.

Boys with high BP had a significantly higher prevalence of eating meat products such as pate (chicken, liver), meat salami and sausages $(\mathrm{p}=0.015)$ (Table 4).

\section{Discussion}

Epidemiological studies have demonstrated the importance of measuring BP during childhood and adolescence. In one of such studies, Cook et al. estimated risk factors for the prevalence and distribution of metabolic syndrome ${ }^{17}$. One of the selected risk factors was high SBP and/or DBP, which were defined as values at or above the $90^{\text {th }}$ percentile for age, gender and height ${ }^{17}$. This classification was used in our crosssectional study because the aim was to determine dif- ferences in anthropometric measurements, dietary habits, serum lipid and glucose levels in relation to high $\mathrm{BP}$ but not to diagnose hypertension among adolescents. Hypertension is a clinical entity and in order to diagnose it $\mathrm{BP}$ must be constantly monitored and a number of parameters should be taken into account. Furthermore, despite the number of studies that have been performed, the prevalence of high $\mathrm{BP}$ values in pediatric population worldwide is difficult to establish partly due to regional differences in the definition, distribution of reference BP data and methods of BP measurement. Central-European studies showed the prevalence of high BP values in adolescents from as low as $2.2 \%$ in Switzerland to $4.9 \%$ in Poland ${ }^{22-24}$. Data from Southern Europe highlighted a higher prevalence; adolescent hypertension was estimated to be at least $9 \%$ in Turkey to $13 \%$ in Portugal ${ }^{25-27}$. As it is well known, children with average SBP and/or DBP at least in the $90^{\text {th }}$, but less than $95^{\text {th }}$ percentile are classified as having high-normal $\mathrm{BP}^{28}$. High-normal $\mathrm{BP}$ and hypertension are frequently associated with one or more cardiometabolic risk factors. Early identification and intervention or treatment of children with high $\mathrm{BP}$ is very important for preventing or managing hy- 
Table 1. Differences in anthropometric and laboratory values between high ( $\geq 90^{\text {th }}$ percentile) and normal BP groups of adolescent girls

\begin{tabular}{|c|c|c|c|c|c|c|c|c|}
\hline \multirow{2}{*}{\multicolumn{2}{|c|}{$\begin{array}{l}\mathrm{BP} \geq 90^{\text {th }} \text { percentile } \\
(135 / 87.5 \mathrm{~mm} \mathrm{Hg})\end{array}$}} & \multirow{3}{*}{\begin{tabular}{|l|}
$n$ \\
211 \\
35
\end{tabular}} & \multirow{3}{*}{\begin{tabular}{|l|} 
Minimum \\
16.40 \\
15.56
\end{tabular}} & \multirow{3}{*}{$\begin{array}{l}\text { Maximum } \\
52.29 \\
35.27\end{array}$} & \multicolumn{3}{|c|}{ Percentile } & \multirow{3}{*}{\begin{tabular}{|l}
$\mathrm{p}$ \\
0.020
\end{tabular}} \\
\hline & & & & & \multirow{2}{*}{\begin{tabular}{|l|}
$25^{\text {th }}$ \\
19.59 \\
20.81
\end{tabular}} & \multirow{2}{*}{\begin{tabular}{|l}
$50^{\text {th }}($ median $)$ \\
20.93 \\
21.75
\end{tabular}} & \multirow{2}{*}{$\begin{array}{l}75^{\text {th }} \\
22.78 \\
24.00\end{array}$} & \\
\hline $\begin{array}{l}\text { BMI } \\
\left(\mathrm{kg} / \mathrm{m}^{2}\right)\end{array}$ & $\begin{array}{l}\text { No } \\
\text { Yes }\end{array}$ & & & & & & & \\
\hline $\mathrm{WC}(\mathrm{cm})$ & $\begin{array}{l}\text { No } \\
\text { Yes }\end{array}$ & $\begin{array}{l}211 \\
35\end{array}$ & $\begin{array}{l}57.10 \\
59.50\end{array}$ & $\begin{array}{l}103.70 \\
99.10\end{array}$ & $\begin{array}{l}64.60 \\
67.20\end{array}$ & $\begin{array}{l}67.80 \\
72.70\end{array}$ & $\begin{array}{l}71.50 \\
77.30\end{array}$ & 0.002 \\
\hline WHR & $\begin{array}{l}\text { No } \\
\text { Yes }\end{array}$ & $\begin{array}{l}211 \\
35\end{array}$ & $\begin{array}{l}0.65 \\
0.66\end{array}$ & $\begin{array}{l}1.27 \\
0.88\end{array}$ & $\begin{array}{l}0.71 \\
0.71\end{array}$ & $\begin{array}{l}0.73 \\
0.74\end{array}$ & $\begin{array}{l}0.75 \\
0.78\end{array}$ & 0.043 \\
\hline WHtR & $\begin{array}{l}\text { No } \\
\text { Yes }\end{array}$ & $\begin{array}{l}211 \\
35\end{array}$ & $\begin{array}{l}0.34 \\
0.34\end{array}$ & $\begin{array}{l}0.59 \\
0.59\end{array}$ & $\begin{array}{l}0.39 \\
0.39\end{array}$ & $\begin{array}{l}0.41 \\
0.43\end{array}$ & $\begin{array}{l}0.43 \\
0.45\end{array}$ & 0.016 \\
\hline $\mathrm{HC}(\mathrm{cm})$ & $\begin{array}{l}\text { No } \\
\text { Yes }\end{array}$ & $\begin{array}{l}211 \\
35\end{array}$ & $\begin{array}{l}51.60 \\
86.40\end{array}$ & $\begin{array}{l}123.60 \\
113.10\end{array}$ & $\begin{array}{l}89.90 \\
91.20\end{array}$ & $\begin{array}{l}93.10 \\
96.80\end{array}$ & $\begin{array}{l}98.00 \\
104.50\end{array}$ & 0.015 \\
\hline $\begin{array}{l}\text { Skin fold } \\
(\mathrm{mm})\end{array}$ & $\begin{array}{l}\text { No } \\
\text { Yes }\end{array}$ & $\begin{array}{l}211 \\
35\end{array}$ & $\begin{array}{l}6.40 \\
7.80 \\
\end{array}$ & $\begin{array}{l}40.00 \\
44.60\end{array}$ & $\begin{array}{l}13.20 \\
12.20\end{array}$ & $\begin{array}{l}17.00 \\
20.20\end{array}$ & $\begin{array}{l}22.70 \\
25.80\end{array}$ & 0.283 \\
\hline $\begin{array}{l}\text { TG } \\
(\mathrm{mmol} / \mathrm{L})\end{array}$ & $\begin{array}{l}\text { No } \\
\text { Yes }\end{array}$ & $\begin{array}{l}207 \\
33\end{array}$ & $\begin{array}{l}0.30 \\
0.38\end{array}$ & $\begin{array}{l}2.25 \\
1.90\end{array}$ & $\begin{array}{l}0.53 \\
0.71\end{array}$ & $\begin{array}{l}0.72 \\
0.80\end{array}$ & $\begin{array}{l}0.94 \\
1.01\end{array}$ & 0.021 \\
\hline $\begin{array}{l}\text { Fasting glucose } \\
(\mathrm{mmol} / \mathrm{L})\end{array}$ & $\begin{array}{l}\text { No } \\
\text { Yes }\end{array}$ & $\begin{array}{l}207 \\
33\end{array}$ & $\begin{array}{l}3.40 \\
3.60\end{array}$ & $\begin{array}{l}13.30 \\
6.00\end{array}$ & $\begin{array}{l}4.10 \\
4.25\end{array}$ & $\begin{array}{l}4.40 \\
4.40\end{array}$ & $\begin{array}{l}4.60 \\
4.70\end{array}$ & 0.332 \\
\hline $\begin{array}{l}\text { HDL-c } \\
(\mathrm{mmol} / \mathrm{L})\end{array}$ & $\begin{array}{l}\text { No } \\
\text { Yes }\end{array}$ & $\begin{array}{l}207 \\
33\end{array}$ & $\begin{array}{l}0.81 \\
1.05\end{array}$ & $\begin{array}{l}2.87 \\
2.03\end{array}$ & $\begin{array}{l}1.30 \\
1.29\end{array}$ & $\begin{array}{l}1.50 \\
1.53\end{array}$ & $\begin{array}{l}1.72 \\
1.68\end{array}$ & 0.660 \\
\hline $\begin{array}{l}\text { TC } \\
(\mathrm{mmol} / \mathrm{L})\end{array}$ & $\begin{array}{l}\text { No } \\
\text { Yes }\end{array}$ & $\begin{array}{l}207 \\
33\end{array}$ & $\begin{array}{l}2.09 \\
2.77\end{array}$ & $\begin{array}{l}7.00 \\
6.00\end{array}$ & $\begin{array}{l}3.64 \\
3.69\end{array}$ & $\begin{array}{l}4.16 \\
4.11\end{array}$ & $\begin{array}{l}4.71 \\
4.57\end{array}$ & 0.989 \\
\hline
\end{tabular}

$\mathrm{BP}=$ blood pressure; $\mathrm{BMI}=$ body mass index $\mathrm{WC}=$ waist circumference; $\mathrm{WHR}=$ waist-to-hip ratio $\mathrm{HC}=$ hip circumference; $\mathrm{WHtR}=$ waist-to-height ratio; $\mathrm{TG}=$ triglycerides $\mathrm{HDL}-\mathrm{c}=\mathrm{HDL}$ cholesterol; $\mathrm{TC}=$ total cholesterol

pertension, as well as BP-related cardiovascular diseases in adulthood 7 .

Diagnostic criteria for elevated BP in children are based on the concept that BP in children increases with age and body size, making it impossible to determine a single BP level to define hypertension, as done in adults ${ }^{8}$. Therefore, the above data were supported in our study, where it was shown that DBP values increased in adolescent boys and girls with age, whereas a decrease in SBP was observed in adolescent girls. In our study, the values of SBP and DBP recorded in adolescent boys and DBP values in girls were in line with the data mentioned above. The decrease in SBP with age in girls could be explained by new findings in monitoring gender differences in $\mathrm{BP}$ values ${ }^{28}$, or potentially due to study limitations in terms of sample size. In support of the hypothesis on the sample size, 111 adolescent boys and 246 girls participated in our study. The findings indicated that 31 (27.93\%) boys and 35 (14.69\%) girls had high BP. There were almost two times more boys with high BP compared to girls. Although there was a study that determined the prevalence of high normal and elevated BP in 965 healthy schoolchildren ( $48.7 \%$ of girls) in final $\left(8^{\text {th }}\right)$ grade of elementary school and $3^{\text {rd }}$ grade of secondary school in Croatia ${ }^{29}$, there still is not enough new data on healthy high school students from Croatia to determine the prevalence of high BP. In our study, differences were found in anthropometric and laboratory values between high and normal BP groups of adolescents. $\mathrm{BMI}$ is an established risk factor for high $\mathrm{BP}$ and has the strongest effect on BP in obese children and adolescents ${ }^{30}$. It would increase along with BMI increase, confirming the results of our study, which concluded that both adolescent girls and boys with high BP had a significantly higher BMI ( $\mathrm{p}=0.020$ and $\mathrm{p}=0.045$, re- 
Table 2. Differences in anthropometric and laboratory values between high ( $\geq 90^{\text {th }}$ percentile) and normal BP groups of adolescent boys

\begin{tabular}{|c|c|c|c|c|c|c|c|c|}
\hline \multirow{2}{*}{\multicolumn{2}{|c|}{$\begin{array}{l}\mathrm{BP} \geq 90^{\text {th }} \text { percentile } \\
(135 / 87.5 \mathrm{~mm} \mathrm{Hg})\end{array}$}} & \multirow{3}{*}{\begin{tabular}{|l|}
$n$ \\
80 \\
31
\end{tabular}} & \multirow{3}{*}{\begin{tabular}{|l|} 
Minimum \\
16.79 \\
16.70 \\
\end{tabular}} & \multirow{3}{*}{$\begin{array}{l}\text { Maximum } \\
30.86 \\
31.46\end{array}$} & \multicolumn{3}{|c|}{ Percentile } & \multirow{3}{*}{$\begin{array}{l}p \\
0.045\end{array}$} \\
\hline & & & & & \multirow{2}{*}{\begin{tabular}{|l|}
$25^{\text {th }}$ \\
19.57 \\
20.34
\end{tabular}} & \multirow{2}{*}{$\begin{array}{l}50^{\text {th }} \text { (median) } \\
21.15 \\
22.32\end{array}$} & \multirow{2}{*}{$\begin{array}{l}75^{\text {th }} \\
23.39 \\
25.68\end{array}$} & \\
\hline $\begin{array}{l}\mathrm{BMI} \\
\left(\mathrm{kg} / \mathrm{m}^{2}\right)\end{array}$ & $\begin{array}{l}\text { No } \\
\text { Yes }\end{array}$ & & & & & & & \\
\hline WC & $\begin{array}{l}\text { No } \\
\text { Yes }\end{array}$ & $\begin{array}{l}80 \\
31\end{array}$ & $\begin{array}{l}62.10 \\
62.50\end{array}$ & $\begin{array}{l}91.70 \\
97.00\end{array}$ & $\begin{array}{l}69.05 \\
72.20\end{array}$ & $\begin{array}{l}72.65 \\
78.30\end{array}$ & $\begin{array}{l}78.00 \\
83.30\end{array}$ & 0.004 \\
\hline WHR & $\begin{array}{l}\text { No } \\
\text { Yes }\end{array}$ & $\begin{array}{l}80 \\
31\end{array}$ & $\begin{array}{l}0.67 \\
0.72\end{array}$ & $\begin{array}{l}0.86 \\
0.91\end{array}$ & $\begin{array}{l}0.75 \\
0.79\end{array}$ & $\begin{array}{l}0.79 \\
0.81\end{array}$ & $\begin{array}{l}0.81 \\
0.82\end{array}$ & 0.022 \\
\hline WHtR & $\begin{array}{l}\text { No } \\
\text { Yes }\end{array}$ & $\begin{array}{l}80 \\
31\end{array}$ & $\begin{array}{l}0.35 \\
0.35\end{array}$ & $\begin{array}{l}0.53 \\
0.56\end{array}$ & $\begin{array}{l}0.39 \\
0.41\end{array}$ & $\begin{array}{l}0.41 \\
0.43\end{array}$ & $\begin{array}{l}0.43 \\
0.46\end{array}$ & 0.017 \\
\hline $\mathrm{HC}(\mathrm{cm})$ & $\begin{array}{l}\text { No } \\
\text { Yes }\end{array}$ & $\begin{array}{l}80 \\
31\end{array}$ & $\begin{array}{l}81.50 \\
81.60\end{array}$ & $\begin{array}{l}117.70 \\
110.00\end{array}$ & $\begin{array}{l}89.20 \\
91.80\end{array}$ & $\begin{array}{l}93.70 \\
97.40\end{array}$ & $\begin{array}{l}98.10 \\
100.20\end{array}$ & 0.056 \\
\hline $\begin{array}{l}\text { Skin fold } \\
(\mathrm{mm})\end{array}$ & $\begin{array}{l}\text { No } \\
\text { Yes }\end{array}$ & $\begin{array}{l}80 \\
31\end{array}$ & $\begin{array}{l}5.40 \\
5.00\end{array}$ & $\begin{array}{l}107.20 \\
27.00\end{array}$ & $\begin{array}{l}8.00 \\
8.00\end{array}$ & $\begin{array}{l}11.65 \\
11.10\end{array}$ & $\begin{array}{l}15.10 \\
17.20\end{array}$ & 0.908 \\
\hline $\begin{array}{l}\text { TG } \\
(\mathrm{mmol} / \mathrm{L})\end{array}$ & $\begin{array}{l}\text { No } \\
\text { Yes }\end{array}$ & $\begin{array}{l}80 \\
31\end{array}$ & $\begin{array}{l}0.20 \\
0.31 \\
\end{array}$ & $\begin{array}{l}1.98 \\
6.09\end{array}$ & $\begin{array}{l}0.52 \\
0.53\end{array}$ & $\begin{array}{l}0.66 \\
0.78\end{array}$ & $\begin{array}{l}0.85 \\
1.15\end{array}$ & 0.081 \\
\hline $\begin{array}{l}\text { Fasting glucose } \\
(\mathrm{mmol} / \mathrm{L})\end{array}$ & $\begin{array}{l}\text { No } \\
\text { Yes }\end{array}$ & $\begin{array}{l}80 \\
31\end{array}$ & $\begin{array}{l}3.70 \\
3.80\end{array}$ & $\begin{array}{l}5.60 \\
5.40\end{array}$ & $\begin{array}{l}4.20 \\
4.40\end{array}$ & $\begin{array}{l}4.50 \\
4.70\end{array}$ & $\begin{array}{l}4.80 \\
4.90\end{array}$ & 0.108 \\
\hline $\begin{array}{l}\text { HDL-c } \\
(\mathrm{mmol} / \mathrm{L})\end{array}$ & $\begin{array}{l}\text { No } \\
\text { Yes }\end{array}$ & $\begin{array}{l}80 \\
31\end{array}$ & $\begin{array}{l}0.91 \\
0.75\end{array}$ & $\begin{array}{l}2.12 \\
1.94\end{array}$ & $\begin{array}{l}1.16 \\
1.17\end{array}$ & $\begin{array}{l}1.30 \\
1.39\end{array}$ & $\begin{array}{l}1.52 \\
1.53\end{array}$ & 0.765 \\
\hline $\begin{array}{l}\text { TC } \\
(\mathrm{mmol} / \mathrm{L})\end{array}$ & $\begin{array}{l}\text { No } \\
\text { Yes }\end{array}$ & $\begin{array}{l}80 \\
31\end{array}$ & $\begin{array}{l}2.53 \\
2.45\end{array}$ & $\begin{array}{l}7.04 \\
6.42\end{array}$ & $\begin{array}{l}3.34 \\
3.29\end{array}$ & \begin{tabular}{|l}
3.91 \\
3.96
\end{tabular} & $\begin{array}{l}4.39 \\
4.53\end{array}$ & 0.990 \\
\hline
\end{tabular}

$B P=$ blood pressure; $B M I=$ body mass index; $W C=$ waist circumference; $W H R=$ waist-to-hip ratio; $H C=$ hip circumference; $W H t R=$ waist-to-height ratio; $T G=$ triglycerides; $H D L-c=H D L$ cholesterol; $T C=$ total cholesterol

spectively). These findings were in line with expectations since a number of studies have confirmed close association between BMI and prevalence of high BP in children and adolescents ${ }^{31,32}$. According to sex, girls with high BP had more significant associations between high BP and BMI ( $\mathrm{p}=0.020)$ as compared to boys with high $\mathrm{BP}(\mathrm{p}=0.045)$. These results showed the girls with high $\mathrm{BP}$ to be more exposed to obesity in comparison to boys with high BP. Compared with generalized obesity, central obesity is more strongly correlated with metabolic risk factors. A number of studies have shown that central obesity is an independent risk factor for type 2 diabetes mellitus, dyslipidemia, systemic arterial hypertension, and coronary artery disease ${ }^{32}$. BMI does not always relate to central obesity and varies with growth and maturation, and cannot differentiate muscle mass from bone and fat mass $^{33}$. Some studies found that after adjustment for
$\mathrm{BMI}$, cardiometabolic risk factors were more prevalent in children and adolescents with abdominal obesity than in those with overweight and general obesity ${ }^{31,34,35}$. WC, WHtR, and WHR were the most common indexes used for defining abdominal obesity, and were also used in our study ${ }^{36}$. The Bogalusa Heart Study showed the distribution of central fat determined by WC at the ages of 5-17 years to be associated with abnormal concentrations of TG, low density lipoprotein cholesterol (LDL-c), HDL-c, and insu$\operatorname{lin}^{33}$. Yet, WHtR showed slightly stronger associations with lipid and lipoprotein concentrations, and BMIfor-age showed slightly stronger associations with measures of fasting insulin and $\mathrm{BPs}^{33}$. In our study, only girls with high BP had a significantly higher level of TG ( $p=0.021)$ in relation to other laboratory values (HDL-c, TC and glucose). 
Table 3. Relationship of dietary habits with high blood pressure (BP) in adolescent girls ( $\chi^{2}$-test)

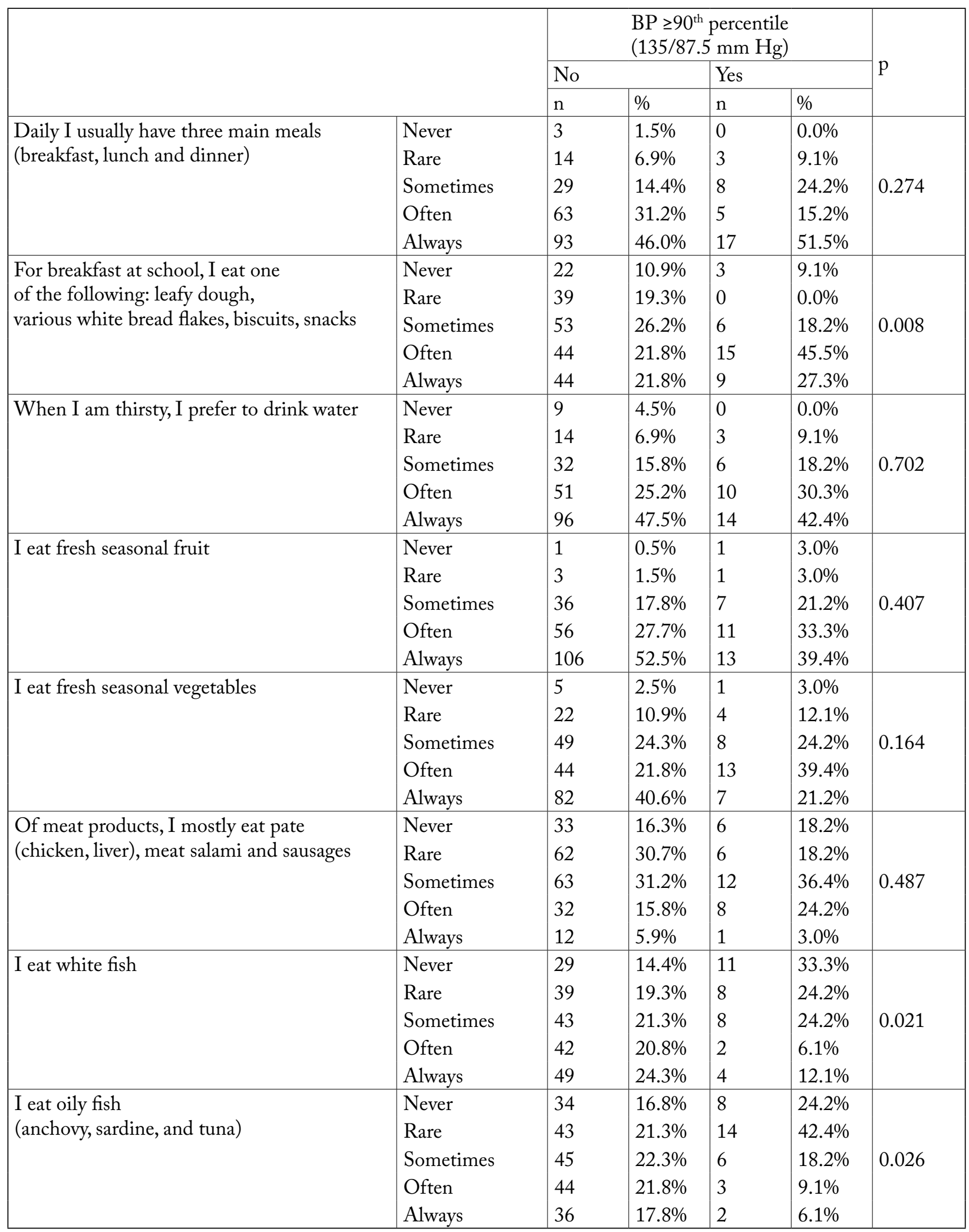


Table 4. Relationship of dietary habits with high blood pressure (BP) in adolescent boys ( $\chi^{2}$-test)

\begin{tabular}{|c|c|c|c|c|c|c|}
\hline & \multicolumn{4}{|c|}{$\begin{array}{l}\mathrm{BP} \geq 90^{\text {th }} \text { percentile } \\
(135 / 87.5 \mathrm{~mm} \mathrm{Hg})\end{array}$} & \multirow{3}{*}{$\mathrm{p}$} \\
\hline & & \multicolumn{2}{|l|}{ No } & \multicolumn{2}{|l|}{ Yes } & \\
\hline & & $\mathrm{n}$ & $\%$ & $\mathrm{n}$ & $\%$ & \\
\hline $\begin{array}{l}\text { Daily, I usually have three main meals } \\
\text { (breakfast, lunch and dinner) }\end{array}$ & $\begin{array}{l}\text { Never } \\
\text { Rare } \\
\text { Sometimes } \\
\text { Often } \\
\text { Always }\end{array}$ & $\begin{array}{l}1 \\
3 \\
10 \\
17 \\
44 \\
\end{array}$ & \begin{tabular}{|l|}
$1.3 \%$ \\
$4.0 \%$ \\
$13.3 \%$ \\
$22.7 \%$ \\
$58.7 \%$ \\
\end{tabular} & $\begin{array}{l}1 \\
2 \\
3 \\
6 \\
19 \\
\end{array}$ & $\begin{array}{l}3.2 \% \\
6.5 \% \\
9.7 \% \\
19.4 \% \\
61.3 \% \\
\end{array}$ & 0.899 \\
\hline $\begin{array}{l}\text { For breakfast at school, I eat one of the } \\
\text { following: leafy dough, various white bread } \\
\text { flakes, biscuits, snacks }\end{array}$ & $\begin{array}{l}\text { Never } \\
\text { Rare } \\
\text { Sometimes } \\
\text { Often } \\
\text { Always }\end{array}$ & $\begin{array}{l}15 \\
19 \\
14 \\
20 \\
7\end{array}$ & $\begin{array}{l}20.0 \% \\
25.3 \% \\
18.7 \% \\
26.7 \% \\
9.3 \% \\
\end{array}$ & $\begin{array}{l}9 \\
4 \\
9 \\
6 \\
3\end{array}$ & $\begin{array}{l}29.0 \% \\
12.9 \% \\
29.0 \% \\
19.4 \% \\
9.7 \%\end{array}$ & 0.417 \\
\hline When I am thirsty, I prefer to drink water & $\begin{array}{l}\text { Never } \\
\text { Rare } \\
\text { Sometimes } \\
\text { Often } \\
\text { Always }\end{array}$ & $\begin{array}{l}7 \\
9 \\
13 \\
20 \\
26\end{array}$ & \begin{tabular}{|l|}
$9.3 \%$ \\
$12.0 \%$ \\
$17.3 \%$ \\
$26.7 \%$ \\
$34.7 \%$ \\
\end{tabular} & \begin{tabular}{|l}
3 \\
4 \\
12 \\
4 \\
8
\end{tabular} & $\begin{array}{l}9.7 \% \\
12.9 \% \\
38.7 \% \\
12.9 \% \\
25.8 \% \\
\end{array}$ & 0.156 \\
\hline I eat fresh seasonal fruit & $\begin{array}{l}\text { Never } \\
\text { Rare } \\
\text { Sometimes } \\
\text { Often } \\
\text { Always }\end{array}$ & $\begin{array}{l}2 \\
4 \\
16 \\
25 \\
28 \\
\end{array}$ & $\begin{array}{l}2.7 \% \\
5.3 \% \\
21.3 \% \\
33.3 \% \\
37.3 \% \\
\end{array}$ & \begin{tabular}{|l}
0 \\
2 \\
11 \\
4 \\
14
\end{tabular} & $\begin{array}{l}0.0 \% \\
6.5 \% \\
35.5 \% \\
12.9 \% \\
45.2 \% \\
\end{array}$ & 0.179 \\
\hline I eat fresh seasonal vegetables & $\begin{array}{l}\text { Never } \\
\text { Rare } \\
\text { Sometimes } \\
\text { Often } \\
\text { Always }\end{array}$ & $\begin{array}{l}4 \\
13 \\
24 \\
18 \\
16 \\
\end{array}$ & \begin{tabular}{|l|}
$5.3 \%$ \\
$17.3 \%$ \\
$32.0 \%$ \\
$24.0 \%$ \\
$21.3 \%$ \\
\end{tabular} & $\begin{array}{l}2 \\
5 \\
13 \\
3 \\
8 \\
\end{array}$ & \begin{tabular}{|l|}
$6.5 \%$ \\
$16.1 \%$ \\
$41.9 \%$ \\
$9.7 \%$ \\
$25.8 \%$ \\
\end{tabular} & 0.533 \\
\hline $\begin{array}{l}\text { Of meat products, I mostly eat pate } \\
\text { (chicken, liver), meat salami and sausages }\end{array}$ & $\begin{array}{l}\text { Never } \\
\text { Rare } \\
\text { Sometimes } \\
\text { Often } \\
\text { Always }\end{array}$ & $\begin{array}{l}14 \\
23 \\
24 \\
11 \\
3\end{array}$ & \begin{tabular}{|l|}
$18.7 \%$ \\
$30.7 \%$ \\
$32.0 \%$ \\
$14.7 \%$ \\
$4.0 \%$ \\
\end{tabular} & $\begin{array}{l}1 \\
6 \\
9 \\
13 \\
2 \\
\end{array}$ & \begin{tabular}{|l|}
$3.2 \%$ \\
$19.4 \%$ \\
$29.0 \%$ \\
$41.9 \%$ \\
$6.5 \%$ \\
\end{tabular} & 0.015 \\
\hline I eat white fish & $\begin{array}{l}\text { Never } \\
\text { Rare } \\
\text { Sometimes } \\
\text { Often } \\
\text { Always }\end{array}$ & $\begin{array}{l}10 \\
12 \\
25 \\
14 \\
14 \\
\end{array}$ & $\begin{array}{l}13.3 \% \\
16.0 \% \\
33.3 \% \\
18.7 \% \\
18.7 \% \\
\end{array}$ & $\begin{array}{l}5 \\
5 \\
8 \\
5 \\
8\end{array}$ & $\begin{array}{l}16.1 \% \\
16.1 \% \\
25.8 \% \\
16.1 \% \\
25.8 \% \\
\end{array}$ & 0.888 \\
\hline $\begin{array}{l}\text { I eat oily fish } \\
\text { (anchovy, sardine, and tuna) }\end{array}$ & $\begin{array}{l}\text { Never } \\
\text { Rare } \\
\text { Sometimes } \\
\text { Often } \\
\text { Always }\end{array}$ & $\begin{array}{l}10 \\
14 \\
26 \\
15 \\
10\end{array}$ & $\begin{array}{l}13.3 \% \\
18.7 \% \\
34.7 \% \\
20.0 \% \\
13.3 \%\end{array}$ & $\begin{array}{l}4 \\
5 \\
14 \\
3 \\
5\end{array}$ & $\begin{array}{l}12.9 \% \\
16.1 \% \\
45.2 \% \\
9.7 \% \\
16.1 \% \\
\end{array}$ & 0.695 \\
\hline
\end{tabular}


Furthermore, girls with high BP had a more significant association between high $\mathrm{BP}$ and $\mathrm{WC}$ ( $p=0.002)$ as compared to boys with high BP $(p=0.004)$, while just girls with high BP had significantly higher $\mathrm{HC}(\mathrm{p}=0.015)$. These findings are in accordance with data reported in a cross-sectional study of Dutch children and adolescents, showing that $\mathrm{WC}$ and $\mathrm{HC}$ values increased with age ${ }^{37}$. The values of WC were slightly higher in girls than in boys, which is opposite to the study on Dutch children from 11 years of age onwards ${ }^{37}$. This can be explained by differences in sample size; in the study conducted in The Netherlands, cross-sectional data were obtained from 14500 children in the age range $0-21$ years in relation to 357 (without missing values) Croatian adolescents aged 14-17 years. The boys with high BP had significantly higher WC $(p=0.004)$ in relation to BMI $(p=0.045)$, and WC $(\mathrm{p}=0.002)$ in girls with high $\mathrm{BP}$ was more strongly associated with CVD risk factors than previously thought for BMI ( $p=0.020)$. WHR was used to estimate fat distribution but later studies suggested that WC itself was a useful measure in its own right. Several studies have also concluded that WHR is more strongly associated with CVD risk factors than is $\mathrm{BMI}^{33,38}$. In accordance with the abovementioned, boys with high BP had significantly higher WHR $(\mathrm{p}=0.022)$ in comparison to their BMI $(\mathrm{p}=0.045)$ but BMI $(\mathrm{p}=0.020)$ in girls with high BP was still more strongly associated with CVD risk factors than was WHR ( $\mathrm{p}=0.043)$. According to gender, boys with high $\mathrm{BP}$ had significantly higher WHR $(\mathrm{p}=0.022)$ in comparison to girls with high $\mathrm{BP}(\mathrm{p}=0.043)$.

The indicator of the relationship between the rate of WC increase and body height is shown by WHtR and changes with age. It is a simple indicator for estimating the CVD risk factors during clinical screening, and it seems to be even more reliable than $\mathrm{WC}$ and BMI. In our study, girls with high BP had significantly higher WHtR ( $\mathrm{p}=0.016)$ as compared with girls with normal BP. Significantly higher values were also observed in boys with high $\mathrm{BP}(\mathrm{p}=0.017)$ compared to those with normal BP. These findings indicate the need for further anthropometric measurement using WHtR as a simple anthropometric index to identify the status of central (visceral) obesity and cardiometabolic risk factor profiles in groups of normal weight and overweight/obese children and adolescents ${ }^{39}$.
Several studies in children and adults have concluded that WHtR is more strongly associated with CVD risk factors than is $\mathrm{BMI}^{33}$. In accordance with the above, boys with high $\mathrm{BP}$ had significantly higher WHtR $(p=0.017)$ in relation to their BMI $(p=0.045)$ and WHtR ( $\mathrm{p}=0.016)$, whereas girls with high BP still had strong association with $\mathrm{CVD}$ risk factors $(\mathrm{p}=0.020)$.

Body weight and BP are closely correlated and obesity-related hypertension contributes further to clustering of cardiovascular risk factors in obesity ${ }^{40}$. Pathophysiological and epidemiological studies have indicated that childhood BP is closely associated with high BP in later life ${ }^{41}$. The prevalence of hypertension is high in overweight and obese adolescents, and higher in boys than in girls ${ }^{42}$. Considering these findings, our study girls with high BP had a significantly higher prevalence of eating leafy dough, various white bread flakes, biscuits, snacks at school breakfast $(p=0.008)$ and lower prevalence of eating white $(p=0.021)$ and oily fish $(\mathrm{p}=0.026)$. Furthermore, boys with high BP had a significantly higher prevalence of eating meat products such as pate (chicken, liver), meat salami and sausages $(p=0.015)$. Considering the relation between foods rich in saturated fatty acids (SFA) and BP in adolescents, it is important to emphasize the intake of SFA because the consumption of SFA is a risk for arterial stiffness and $\mathrm{CVD}^{43}$. Research suggests that the intake of SFA, mono-unsaturated fatty acids (MUFA) and poly-unsaturated fatty acids (PUFA) each affects plasma cholesterol uniquely, production of metabolic and inflammatory markers, BP and arterial stiffness ${ }^{44-47}$. Adolescents are especially vulnerable to the effects of inappropriate nutrient intake because of dieting or weight gain, eating patterns, and food selection $^{48}$. Dwyer et al. concluded that as the number of eating occasions increased outside regular planned meals, so did energy intake from sugars, total carbohydrates, and amounts of sodium ${ }^{49}$. This finding reinforces the importance of adolescents needing three balanced meals a day to reduce the volume of nutrientdeficient eating in which adolescents currently engage.

Rapidity in eating leads to overconsumption of food before satiety is experienced ${ }^{49}$. It is recommended that prehypertension be identified in overweight adolescents and that lifestyle changes be made to avoid its evolution towards obesity and hypertension ${ }^{42}$. Based on data from our study, it is reported that salt intake in 
girls (from consumption of white flour products) and boys (meat products) significantly affected BP. Dietary habits early in life, and particularly high salt intake, have been implicated as factors favoring higher BP values ${ }^{50}$.

\section{Study limitations}

In our study, the average of two BP readings taken during one visit was noted on growth charts for every participant above or equal to the $90^{\text {th }}$ percentile. Because of BP variability, it has been argued that multiple visits are more important than multiple readings per visit in children and adolescents, and more than three measurements per visit may not be needed ${ }^{41}$. Creating the reference values of a particular region greatly increases the chances of a more accurate diagnosis ${ }^{51}$.

Blood tests were performed in all participants except for 24 participants who had fear of needles or were absent on the day of blood sampling. Conclusions are similar and consistent with the research conducted on 1100 adolescents in Algeria ${ }^{42}$. The large sample size, performing measurements at multiple time intervals and diagnosing hypertension not just upon high BP would be important for a more detailed determination of differences in anthropometric measurements, dietary habits, serum lipid and glucose levels regarding high $\mathrm{BP}$ and hypertension among adolescent boys and girls in Croatia.

\section{Conclusions}

We determined differences in anthropometric measurements and dietary habits regarding high BP among adolescent boys and girls in Croatia. Differences in the values of BMI, WC, HC, WHtR and WHR are significant and represent indicators for estimating the CVD risk factors in adolescent boys and girls. Also, these significant differences point to the close association of BMI, WC, HC,WHtR and WHR and the prevalence of high $\mathrm{BP}$ in Croatian adolescents.

According to gender, the most significant differences were recorded for $\mathrm{WC}(\mathrm{p}=0.004)$ in adolescent boys and $\mathrm{HC}(\mathrm{p}=0.015)$ in girls. These findings confirm the expectations obtained in the previously mentioned Bogalusa Heart Study, which found the distribution of central fat to be determined by WC at the ages of 5-17 years and associated with higher levels of
$\mathrm{TG}^{39}$. The central body fat deposition in children and adolescents increases cardiometabolic risks ${ }^{52}$. Furthermore, more attention should be paid to abdominal obesity in children and adolescents, both in clinical practice and in epidemiological studies ${ }^{36}$. First-line interventions should aim at $\mathrm{BP}$ normalization and weight reduction ${ }^{51}$. A healthy lifestyle with daily physical activity and a low-sodium diet rich in fruit and vegetables, low in carbohydrates and sugar-sweetened beverages, is strongly recommended ${ }^{8,40,53}$. Further research into these factors could lead to better methods of controlling the increasing BP among Croatian adolescents, which might in turn contribute to decreasing the risk of CVD in adulthood.

Ambulatory BP monitoring is highly recommended before pharmacological treatment is started ${ }^{51}$.

\section{Acknowledgment}

The authors wish to acknowledge the work of laboratory staff who took part in study sample analysis.

\section{References}

1. Archibald Bastiani A, Graber Ja, Brooks-Gunn J. Overview of pubertal development. In: Adams Gr, Berzonsky M, editors. Pubertal Processes and Physiological Growth in Adolescence. Oxford: Blackwell Publishing Ltd.; 2008. p. 24-47, https://doi. org/10.1002/9780470756607.ch2.

2. Temple NJ, Wilson T, Bray GA, editors. Nutrition Guide for Physicians and Related Healthcare Professionals. $2^{\text {nd }}$ edn. Springer International Publishing; 2017, https://doi.org/ 10.1007/978-3-319-49929-1.

3. Hermans RCJ, De Bruin H, Larsen JK, Mensink F, Hoek AC. Adolescents' responses to a school-based prevention program promoting healthy eating at school. Front Public Health. 2017;5:309, https://doi.org/10.3389/FPUBH.2017.00309.

4. Hamřík Z, Sigmundová D, Pavelka J, Kalman M, Sigmund E. Trends in overweight and obesity in Czech school children from 1998 to 2014. Cent Eur J Public Health. 2017;25:s10-s4, https://doi.org/10.21101/cejph.a5099.

5. United Nations Children's Fund. The State of the World's Children. Adolescence: An Age of Opportunity. UNICEF, United Nations Children's Fund; 2011, https://doi.org/ 10.18356/ace83794-en.

6. Goluch-Koniuszy Z, Kuchlewska M. Body composition in 13-year-old adolescents with abdominal obesity, depending on the BMI value. Adv Clin Exp Med. 2017;26:973-9, https:// doi.org/10.17219/acem/61613.

7. Xi B, Zhang T, Zhang M, Liu F, Zong X, Zhao M, et al. Trends in elevated blood pressure among US children and adolescents: 
1999-2012. Am J Hypertens. 2016;29:217-25, https://doi. org/10.1093/ajh/hpv091.

8. Lurbe E, Cifkova R, Cruickshank JK, Dillon MJ, Ferreira I, Invitti $\mathrm{C}$, et al. Management of high blood pressure in children and adolescents: recommendations of the European Society of Hypertension. J Hypertens. 2009;27:1719-42, https://doi. org/10.1097/HJH.0b013e32832f4f6b.

9. Leiba A, Twig G, Levine H, Goldberger N, Afek A, Shamiss A, et al. Hypertension in late adolescence and cardiovascular mortality in midlife: a cohort study of 2.3 million $16-$ to 19-year-old examinees. Pediatr Nephrol. 2016;31:485-92, https://doi.org/10.1007/s00467-015-3240-1.

10. Yang L, Hou Y, Zhao M, Bovet P, Xi B. Simplified blood pressure tables based on different height percentiles for screening elevated blood pressure in children. J Hypertens. 2019;37 (2):292-6, https://doi.org/10.1097/hjh.0000000000001880.

11. Mendizábal B, Urbina EM, Becker R, Daniels SR, Falkner BE, Hamdani G, et al. SHIP-AHOY (Study of High Blood Pressure in Pediatrics: Adult Hypertension Onset in Youth). Hypertension. 2018;72:625-31, https://doi.org/10.1161/hypertensionaha.118.11434.

12. Dekanić D, Duraković Z, Gomzi M, Grgić Z, Haramut M, Heimer $\mathrm{S}$, et al. Fiziološke metode $\mathrm{u}$ antropologijskim istraživanjima. In: Praktikum biološke antropologije. Zagreb: Republički savez samoupravnih interesnih zajednica za zapošljavanje Hrvatske: Republička zajednica za znanstveni rad SR Hrvatske: Sekcija za biološku antropologiju Zbora liječnika hrvatske: Hrvatsko antropološko društvo: Institut za medicinska istraživanja i medicinu rada Sveučilišta; 1987.p. 10-134. (in Croatian)

13. Ogden CL, Carroll MD, Kit BK, Flegal KM. Prevalence of obesity and trends in body mass index among US children and adolescents, 1999-2010. JAMA. 2012;307:483-90, https://doi. org/10.1001/jama.2012.40.

14. Li C, Ford ES, Mokdad AH, Cook S. Recent trends in waist circumference and waist-height ratio among US children and adolescents. Pediatrics. 2006;118:(5):1390-8, https://doi.org/ 10.1542/peds.2006-1062.

15. Jaeschke L, Steinbrecher A, Pischon T. Measurement of waist and hip circumference with a body surface scanner: feasibility, validity, reliability, and correlations with markers of the metabolic syndrome. PLOS One. 2015;10:1-16, https://doi. org/10.1371/journal.pone.0119430.

16. Olutekunbi OA, Solarin AU, Senbanjo IO, Disu EA, Njokanma OF. Skinfold thickness measurement in term Nigerian neonates: establishing reference values. Int J Pediatr. 2018;2018: 1-10, https://doi.org/10.1155/2018/3624548.

17. Cook S, Weitzman M, Auinger P, Nguyen M, Dietz WH. Prevalence of a metabolic syndrome phenotype in adolescents. Arch Pediatr Adolesc Med. 2003;157(8):821, https://doi. org/10.1001/archpedi.157.8.821.

18. Altman DG. Construction of age-related reference centiles using absolute residuals. Stat Med. 1993;12:917-24, https://doi. org/10.1002/sim.4780121003.
19. Altman DG, Chitty LS. Design and analysis of studies to derive charts of fetal size. Ultrasound Obstet Gynecol. 1993;3: 378-84, https://doi.org/10.1046/j.1469-0705.1993.03060378.x.

20. Wright EM, Royston P. Simplified estimation of age-specific reference intervals for skewed data. Stat Med. 1997;16:2785803, https://doi.org/10.1002/(SICI)1097-0258(19971230)16: 24\%3C2785::AID-SIM797\%3E3.0.CO;2-Z.

21. Altman DG, Chitty LS. Charts of fetal size: 1 . Methodology. Br J Obstet Gynaecol.1994;101:29-34, https://dx.doi.org/ 10.1111/j.1471-0528.1994.tb13006.x

22. Chiolero A, Cachat F, Burnier M, Paccaud F, Bovet P. Prevalence of hypertension in schoolchildren based on repeated measurements and association with overweight. J Hypertens. 2007;25: 2209-17, https://doi.org/10.1097/hjh.0b013e3282ef48b2.

23. Ostrowska-Nawarycz L, Nawarycz T. Prevalence of excessive body weight and high blood pressure in children and adolescents in the city of Łódź. Kardiol Pol. 2007;65:1079-87, https://doi.org/10.1097/hjh.0b013e3282ef48b2.

24. Jakab AE, Hidvégi EV, Illyés M, Cziráki A, Bereczki C. Prevalence of overweight and obesity in Hungarian children and adolescents. Ann Nutr Metab. 2018;72:(4):259-64, https://doi. org/10.1159/000487929.

25. Tirosh A, Afek A, Rudich A, Percik R, Gordon B, Ayalon N, et al. Progression of normotensive adolescents to hypertensive adults: a study of 26980 teenagers. Hypertension. 2010;56: 203-9, https://doi.org/10.1161/hypertensionaha.109.146415.

26. Papandreou D, Stamou M, Malindretos P, Rousso I, Mavromichalis I. Prevalence of hypertension and association of dietary mineral intake with blood pressure in healthy schoolchildren from northern Greece aged 7-15 years. Ann Nutr Metab. 2007; 51:471-6, https://doi.org/ 10.1159/000111169.

27. Maldonado J, Pereira T, Fernandes R, Santos R, Carvalho M. An approach of hypertension prevalence in a sample of 5381 Portuguese children and adolescents. The Aveleira Registry. 'Hypertension In Children'. Blood Press. 2011;20:153-7, https://doi.org/10.3109/08037051.2010.542649.

28. Lurbe E, Agabiti-Rosei E, Cruickshank Jk, Dominiczak A, Erdine S, Hirth A, et al. 2016 European Society of Hypertension Guidelines for the Management of High Blood Pressure in Children and Adolescents. J Hypertens. 2016;34(10):1887920, https://doi.org/10.1097/hjh.0000000000001039.

29. Jureša V, Kujundžić M. Growth charts for Croatian school children and secular trends in past twenty years. Coll Antropol. 2012;36:47. (in Croatian)

30. Shi Y, De Groh M, Morrison H. Increasing blood pressure and its associated factors in Canadian children and adolescents from the Canadian Health Measures Survey. BMC Public Health. 2012;12:388, https://doi.org/10.1186/1471-2458-12-388.

31. Benmohammed K, Nguyen MT, Khensal S, Valensi P, Lezzar A. Arterial hypertension in overweight and obese Algerian adolescents: role of abdominal adiposity. Diabetes Metab Rev. 2011;37:291-7, https://doi.org/10.1016/j.diabet.2010.10.010.

32. Larsson B, Svardsudd K, Welin L, Wilhelmsen L, Bjorntorp P, Tibblin G. Abdominal adipose tissue distribution, obesity, and 
risk of cardiovascular disease and death: 13 year follow up of participants in the study of men born in 1913. BMJ. 1984; 288:1401-4, https://doi.org/10.1136/bmj.288.6428.1401.

33. Freedman DS, Kahn HS, Mei Z, Grummer-Strawn LM, Dietz $\mathrm{WH}$, Srinivasan SR, et al. Relation of body mass index and waist-to-height ratio to cardiovascular disease risk factors in children and adolescents: the Bogalusa Heart Study. Am J Clin Nutr. 2007;86:33-40, https://doi.org/10.1093/ajen/86.1.33.

34. Chen B, Li HF. Waist circumference as an indicator of high blood pressure in preschool obese children. Asia Pac J Clin Nutr. 2011;20(4):557-62, https://doi.org/10.6133/apjen.2011. 20.4.09.

35. Plourde G. Impact of obesity on glucose and lipid profiles in adolescents at different age groups in relation to adulthood. BMC Fam Pract. 2002;3:1-14, 10.1186/1471-2296-3-18, https://doi.org/10.1186/1471-2296-3-18.

36. Kelishadi R, Mirmoghtadaee P, Najafi HKM. Systematic review on the association of abdominal obesity in children and adolescents with cardio-metabolic risk factors. J Res Med Sci. 2015;20:294-307.

37. Fredriks AM, van Buuren S, Fekkes M, Verloove-Vanhorick SP, Wit JM. Are age references for waist circumference, hip circumference and waist-hip ratio in Dutch children useful in clinical practice? Eur J Pediatr. 2005;164:216-22, https://doi. org/10.1007/s00431-004-1586-7.

38. Neovius M, Rasmussen F. Evaluation of BMI-based classification of adolescent overweight and obesity: choice of percentage body fat cutoffs exerts a large influence. The Compass Study. Eur J Clin Nutr. 2008;62:1201-7, https://doi.org/10.1038/sj. ejcn.1602846.

39. Mokha JS, Srinivasan SR, Dasmahapatra P, Fernandez C, Chen $\mathrm{W}, \mathrm{Xu}$ J, et al. Utility of waist-to-height ratio in assessing the status of central obesity and related cardiometabolic risk profile among normal weight and overweight/obese children: the Bogalusa Heart Study. BMC Pediatr. 2010;10:73, https:// doi.org/10.1186/1471-2431-10-73.

40. Court JM, Hill GJ, Dunlop M, Boulton TJC. Hypertension in childhood obesity. J Paediatr Child Health. 1974;10:296-300, https://doi.org/10.1111/j.1440-1754.1974.tb02787.x.

41. Chen X, Wang Y. Tracking of blood pressure from childhood to adulthood: a systematic review and meta-regression analysis. Circulation. 2008;117:3171-80, https://doi.org/10.1161/CIRCULATIONAHA.107.730366.

42. Benmohammed K, Valensi P, Nguyen MT, Benmohammed F, Benlatreche M, Benembarek K, Lezzar A. Influence of waist circumference on blood pressure status in non-obese adoles- cents. Int J Adolesc Med Health. 2018;1-7, https://doi. org/10.1515/ijamh-2017-0127.

43. Livingstone KM, Givens DI, Cockcroft JR, Pickering JE, Lovegrove JA. Is fatty acid intake a predictor of arterial stiffness and blood pressure in men? Evidence from the Caerphilly Prospective Study. Nutr Metab Cardiovasc Dis. 2013;23:1079-85, https://doi.org/10.1016/j.numecd.2012.12.002.

44. Hunter JE, Zhang J, Kris-Etherton PM. Cardiovascular disease risk of dietary stearic acid compared with trans, other saturated, and unsaturated fatty acids: a systematic review. Am J Clin Nutr. 2010;91:46-63, https://doi.org/10.3945/ajcn.2009.27661.

45. Nicholls SJ, Lundman P, Harmer JA, Cutri B, Griffiths KA, Rye KA, Barter PJ, Celermajer DS. Consumption of saturated fat impairs the anti-inflammatory properties of high-density lipoproteins and endothelial function. J Am Coll Cardiol. 2006;48:715-20, https://doi.org/10.1016/j.jacc.2006.04.080.

46. Kuipers RS, De Graaf DJ, Luxwolda MF, Muskiet MHA, Muskiet FAJ. Saturated fat, carbohydrates and cardiovascular disease. Neth J Med. 2011 sep;69(9):372-8, https://doi. org/10.3945/ajcn.2008.26285.

47. Vafeiadou K, Weech M, Sharma V, Yaqoob P, Todd S, Williams $\mathrm{CM}$, et al. A review of the evidence for the effects of total dietary fat, saturated, monounsaturated and $n-6$ polyunsaturated fatty acids on vascular function, endothelial progenitor cells and microparticles. Br J Nutr. 2012;107:303-24, https://doi. org/10.1017/s0007114511004764.

48. Jenkins S, Horner SD. Barriers that influence eating behaviors in adolescents. J Pediatr Nurs. 2005;20:258-67, https://doi. org/10.1016/j.pedn.2005.02.014.

49. Dwyer J, Evans M, Stone E, Feldman H, Lytle L, Hoelscher D, et al. Adolescents' eating patterns influence their nutrient intakes. J Am Diet Assoc. 2001;101:798-802, https://doi.org/ 10.1016/S0002-8223(01)00198-5.

50. Geleijnse JM, Grobbee DE. High salt intake early in life: does it increase the risk of hypertension? J Hypertens. 2002;20: 2121-4, https://doi.org/10.1097/00004872-200211000-00003.

51. Pall D, Kiss I, Katona E. Importance of ambulatory blood pressure monitoring in adolescent hypertension. Kidney Blood PressRes.2012;35:129-34,https://doi.org/10.1159/000331057.

52. Klisić A, Kavarić N, Bjelaković B, Soldatović I, Martinović M, Kotur-Stevuljević J. The association between retinol-binding protein 4 and cardiovascular risk score is mediated by waist circumference in overweight/obese adolescent girls. Acta Clin Croat.2017;56:92-8,https://doi.org/10.20471/acc.2017.56.01.14.

53. Rakočević L, Rakočević V. Incidence of cardiovascular risk factors in obese children. Acta Clin Croat. 2016;55:407-13, https://doi.org/10.20471/acc.2016.55.03.09. 
Sažetak

\section{ANTROPOMETRIJSKA MJERENJA, PREHRAMBENE NAVIKE, SERUMSKE RAZINE LIPIDA I GLUKOZE U ODNOSU NA VISOK KRVNI TLAK MEĐU ADOLESCENTNIM DJEVOJKAMA I MLADIĆIMA U HRVATSKOJ}

\section{O. Martinis, M. Čoklo, J. Aladrović, A. Belavić i S. Missoni}

Cilj je bio utvrditi razlike u antropometrijskim mjerenjima, prehrambenim navikama, razinama serumskih lipida i glukoze u odnosu na visok krvni tlak kod adolescentnih djevojaka i mladića u Hrvatskoj. Specifični cilj bio je utvrditi utjecaj prehrambenih navika i načina života na vrijednosti visokog krvnog tlaka kod adolescenata prema spolu. Istraživanje je provedeno na $260(68,2 \%)$ djevojaka i $121(31,8 \%)$ mladića s antropometrijskim podacima dobivenim (bez vrijednosti koje nedostaju) za 246 djevojaka i 111 mladića. Ispitanici su odgovarali na pitanja iz anketnog upitnika. Provedena su antropometrijska mjerenja, mjerenja krvnog tlaka i laboratorijske pretrage. Neparametrijski testovi primijenjeni su u analizama za referentni interval sistoličkog i dijastoličkog krvnog tlaka kod adolescentica i adolescenata s obzirom na njihovu dob. Visok krvni tlak definiran je kao tlak $\geq 90$ centile odnosno $\geq 135 / 87,5 \mathrm{~mm} \mathrm{Hg}$. Mann-Whitneyjev $U$ test primijenjen je za analizu razlika u antropometrijskim i laboratorijskim vrijednostima između skupina djevojaka i mladića s visokim ( $\geq 90$. centile) i normalnim krvnim tlakom. Kod adolescenata je zabilježen trend porasta sistoličkog i dijastoličkog krvnog tlaka. Trend porasta dijastoličkog tlaka pojavljuje se i kod djevojaka u starijoj dobi, dok se sistolički krvni tlak smanjuje. Djevojke s visokim krvnim tlakom imale su značajno veći indeks tjelesne mase $(p=0,020)$, opseg struka $(p=0,002)$, omjer struka i visine $(p=0,016)$, omjer struka i bokova $(\mathrm{p}=0,043)$, opseg kukova $(\mathrm{p}=0,015)$, povišenu razinu triglicerida $(\mathrm{p}=0,021)$, veću učestalost nezdrave prehrane tijekom školskog doručka $(\mathrm{p}=0,008)$ i nižu učestalost jedenja ribe $(\mathrm{p}=0,02)$. Mladići s visokim krvnim tlakom imali su značajno veći indeks tjelesne mase $(\mathrm{p}=0,045)$, opseg struka $(\mathrm{p}=0,004)$, omjer struka i bokova $(\mathrm{p}=0,022)$, omjer struka i visine $(\mathrm{p}=0,017)$ te veću učestalost konzumacije mesnih proizvoda $(\mathrm{p}=0,015)$. Potrebne su učinkovite zdravstvene intervencije kako bi se smanjio rizik od razvoja kardiovaskularnih bolesti i radi sprječavanja bolesti povezanih s dobi. bolesti

Ključne riječi: Adolescenti; Antropometrijska mjerenja; Krvne pretrage; Prehrambene navike; Visok krvni tlak; Srčanožilne 